\title{
FLOODPLAIN OF THE ORLICE RIVER (EASTERN BOHEMIA, CZECH REPUBLIC): THE NATURAL CENTRE OF BIODIVERSITY
}

\author{
MICHAL VÁVRA \\ University of Hradec Králové, Faculty of Science, Department of Biology, Náměstí \\ Svobody 301, 50002 Hradec Králové, Czech Republic; e-mail: michal.vavra@uhk.cz
}

Received: $15^{\text {th }}$ October 2015 , Accepted: $28^{\text {th }}$ November 2015

\begin{abstract}
The article presents the main results of a field research carried out between 2012 and 2014 . It is a comparison case study of vegetation diversity of pools and dead-end branches of the Orlice River in Eastern Bohemia, Czech Republic. The actual state of wetland vegetation is being compared to data from literature that is several decades old. Botanical survey was conducted in the study area located between the town of Hradec Králové and parishes of Malšovice, Malšova Lhota a Svinary. The research confirmed that dead-end river branches and oxbow lakes form potential refugia of biodiversity of vascular plants in the landscape context of the river area despite the fact that the River Orlice was fully regulated in the urban area of Hradec Králové and the surrounding parishes in the past. Nevertheless, the river area is of a natural character there and belongs to the Nature Park of Orlice since 1996. The local ecosystems are also a part of the important locality of the River Orlice and Elbe. The total of 449 taxons of vascular plants (on the level of species and sub-species) and species rich associations of aquatic and wetland plants were recorded in the study area. Conservation of the water regime in the fluvial landscape and suitable regulation interventions against some spreading invasive species are crucial for the continuing existence of the precious species composition. For this reason the article also includes some management steps.
\end{abstract}

Keywords: Orlice River, Eastern Bohemia, Czech Republic, river oxbows, river floodplain, flood, centre of biodiversity, fluvial landscape, water dynamics, nature protection and management

\section{INTRODUCTION}

The Orlice River is one of the last remaining Czech rivers that have not been extensively regulated in their lowland parts. That is why the stream still naturally develops, new branches and dead-ends form and regular floods occur. The floods repeat several times a year, especially from the end of the 20th century when the ridge of the Orlice Mountains was deforested. Comparing to the end of the 80's when majority of the land surrounding the river was ploughed, the floodplain is nowadays, at the beginning of the 21 st century, permanently grassy. A typical characteristic of the lower reaches is a wide basin with a network of dead-end river branches and pools containing the typical aquatic and wetland vegetation. The pools and dead-end branches are followed by bank vegetation with fragments of the original 
soft-wood vegetation, typical for the valley river basin of the River Orlice. A phenomenon of the entire river basin is precious scattered vegetation. Some dead-end branches become connected during high floods, some are only connected to the river partially; however, majority of them gained the character of oxbow lakes. The water regime in these dead-end branches and oxbow lakes is affected by the fluctuation of the water levels in the Orlice River. Aquatic and wetland vegetation in the river branches and pools is subject to succession. While the branches partially connected with the River Orlice undergo blocked succession, pools are subject to spontaneous succession development demonstrating by a gradual deposition and sedimentation of the pools (e.g. Grohmannová, 2012).

The movement of water in fresh water as well as salt-water ecosystems influences submerged macrophytes that direct the streams - the complex interaction affects the deposition of sediments around aquatic vegetation. The movement of water is an important factor for the growth of macrophytes, typically stimulating the abundance and diversity of macrophytes at low to moderate speeds while higher speeds slow the growth down. On the other hand, the groups of macrophytic vegetation lower the speed of the stream, resulting in higher sedimentation and higher clarity influencing the light permeability. The presence of aquatic macrophytes affects the distribution, composition and size of sediment particles, the germination and growth of the vegetation provides important ecosystem services, including improvement of water quality, sediment stabilisation, increasing water clarity and lowering the level of water erosion (O'Brien, 1981; Dieter, 1990; Kovář et al., 1995; Kovář, 1999; Madsen et al., 2001).

Wetlands are defined based on the Ramsar Declaration as the areas of bogs, marshes, meres and areas covered with water, both, naturally and artificially created, permanent or temporary, with stagnant or flowing water, fresh water or salt-water, including the areas of seas if their depth during low tide does not exceed 6 metres (Ramsar, 1971). The Nature Park Orlice was declared in 1996 based on the legal document of 114/1992 Coll., on nature and landscape conservation in order to protect the river basin important from the landscape point of view regarded as precious piece of nature. The Nature Park Orlice belongs to the largest ones in the Czech Republic thanks to is overall area of 11,462 ha. It follows the stream of the Divoka Orlice River from the boundary of the Protected Landscape Area of Orlicke Mountains in Klášterec nad Orlicí, the stream of the Ticha Orlice River from Mladkov to the confluence of both rivers together with the Spojena Orlice River to Hradce Králové in the overall length of approximately $200 \mathrm{~km}$ (www.belec.trebechovicko.cz). The park was created to preserve the remains of natural and semi-natural ecosystems mainly in the surroundings of old river branches. It also aims to renew some formerly filled river branches and meanders. The river basin, serving as a large proportion of the protection zone of the water source for Hradec Králové should be permanently covered with grassy vegetation and the herbaceous composition of pastures and meadows should be cultivated from improved mixtures towards the natural vegetation composition. A special attention is also to be paid to the scattered woody vegetation and its gradual improvement and preservation. The herbaceous composition of meadows is mainly secondary due to the large scale intensification of agriculture during the 70's and 80's based on a regular biannual regeneration of meadows and pastures in the entire river basin. The Natural Park fulfils the esthetical and recreational functions in its entire length - the river basin represents the recreational base for the surrounding towns and parishes, mainly in the vicinity of Hradce Králové and has been long-term used for the construction of small weekend cottages. Marked tourist routes in lowland or slightly undulating terrain are abundant here; the landscape is suitable for rambling as well as cycling. The river branches also belong to the most sought fishing areas (Faltysová, 1996). 
Vávra M.: Floodplain of the Orlice River (Eastern Bohemia, Czech Republic): the natural centre of biodiversity

The study area is also a part of the Orlice and Elbe European Area of Importance (EAI) CZ0524049 (area of 2,683.18 ha), included in the Natura 2000 network. The boundary of the EAI is formed by the river basin of the Orlice River from the confluence of the Ticha and Divoka Orlice Rivers up to the eastern edge of Hradec Králové. The subject of protection in the EAI Orlice and Elbe is the preserved and functioning meandering river basin of the Orlice River, with numerous dead-end river branches and with a characteristic wetland and associated vegetation. The stream of the Orlice River outside of the built up area is regulated to a minimal extent - only by stone reinforcements in the most eroded parts - in the places of risk for residential dwellings. The flood flows significantly affect the erosion activity of the stream. Meanders are formed and so are new dead-end branches and oxbow lakes, while the old river branches are filled with sediment. The river basin of the Orlice represents an important and extensive ecosystem with functioning natural processes and high diversity of individual succession steps. Due to the fact that majority of arable land has been replaced by permanent grassy areas, the eutrophication and nitrification of alluvial vegetation decreased in the recent years.

Species included under the Natura 2000 additional protection and represented in the area include Eurasian cyprinid fish Aspius aspius, highly endangered dragonfly Ophiogomphus cecilia or vertebrates are represented by the highly endangered Eurasian otter (Lutra lutra). These species are protected under the Council Directive 92/43/EEC, on the conservation of natural habitats and of wild fauna and flora and are listed in Annex II of the Directive as species of interest of the European community the protection of which requires the establishment of special conservation areas. Other important species occurring in the area include Kingfisher (Alcedo atthis), Little ringed plover (Charadrius dubius) or Common Sandpiper (Actitis hypoleucos).

Flora is well studied in the area of the conjoined Orlice River. Precious communities of aquatic vegetation occur there, as well as reed beds, communities of tall sedges, damp Filipendula fallow land, wetland willow scrub, fragmented low forests and following meadow stands with scattered old individuals of low forests woody vegetation. František Černohous and Štěpán Husák (Černohous et Husák, 1978) were mapping the aquatic vegetation composition in East Bohemia in 1970-1974. Kopecký studied distribution, ecology and changes in species composition of river basin vegetation of the River Orlice (Kopecký, 1969a; 1972; 1991), and describes also ecological requirements of species occurring on the Orlice. Faltys focused on extinct, lost and endangered taxons of vascular plants in the area of Eastern Bohemia (Faltys, 1993). A systematic research of aquatic macrophytes in the channel of the Orlice River itself was carried out by Jaroslav Rydlo between 1984 and 1994 (Rydlo, 1995). Rydlo also studied the changes in the occurrence of aquatic macrophytes on the conjoined River Orlice (Rydlo, 2001). Jan Rydlo conducted a systematic research of the vegetation of pools, dead-end river branches and the biotope of the conjoined River Orlice (Rydlo, 2008).

The distribution of pondweeds (Potamogeton sp.) in the river basin of the Orlice River was studied by Kaplan (2002a; 2002b; 2003). Other floristic works in this field deal with common as well as rare taxons of vascular plants (Krčan et Kopecký, 1960; Samková, 1999; Prausová, 2006; 2008). Biotope mapping took River Orlice for the purposes of the Natura 2000 network (Prausová, 2003). On the locality of Rameno by Stříbrný rybník (Prausová, 2004; 2010) is carried out an ongoing in situ rescue programme for Potamogeton praelongus where the problems of biology and ecology of this species, as well as the possibilities of repatriation, success of planting and the overall possibility for regeneration and preservation of the critically endangered species are being discussed. 
The dynamics of the water regime in the Orlice River supports the propagation of plants disturbing the natural composition of the community. The spread of invasive species of Japanese knotweed (Reynoutria japonica) and Himalayan balsam (Impatiens glandulifera) is so intense that the natural communities along the rivers recede (Faltysová et al., 2002). Prausová (2009) studied the distribution of geographically non-indigenous and invasive species of vascular plants in the river basin of the Orlice between Hradec Králové and Týniště nad Orlicí.

The main aim of this work was to capture the vegetation of aquatic and wetland communities in pools, dead-end river branches and disused channels of the Orlice River through the methods of floristic lists and phytocoenological research. Selected localities and compared from the point of view $\mathrm{f}$ various stages of the succession development, the state of biodiversity, occurrence of protected and invasive species of vascular plants. The management of localities and care for adjacent areas are also discussed.

\section{CHARACTERISTICS OF THE AREA AND METHODS}

The study focuses on the channel of the Orlice River, located in the catchment area of the River Elbe and its largest east-Bohemian tributary. Twelve localities were selected for the study of succession development of pools, dead-end river branches and oxbow lakes on the Orlice River (Fig. 1) in the cadastral areas of Slezské Předměstí, Malšovice and Malšova Lhota. These are the pools, dead-end river branches and oxbow lakes of Bejkovna, Černé jezero, Hluboké jezero, Holštejn, Kašparovo jezero, Jezuitská jezera, Pekelská jezera, Pod auty, Rameno by Stř́ibrný rybník, Stará Orlice, Sýkorky and V Lukách. Seven pools and dead-end river branches were selected in the cadastral area of Slezské Předměstí: Holštejn, V Lukách, Pekelská jezera, Kašparovo jezero, Hluboké jezero, Černé jezero and Pod auty. Four pools and dead-end river branches were chosen in the cadastral area of Malšovice u Hradce Králové: Bejkovna, Jezuitská jezera, Sýkorky and Stará Orlice. A single selected locality falls to the cadastral area of Malšova Lhota and that is Rameno by Stř́brný rybník.

\section{Fig. 1: Map showing the area of study in the river basin of the Orlice River}

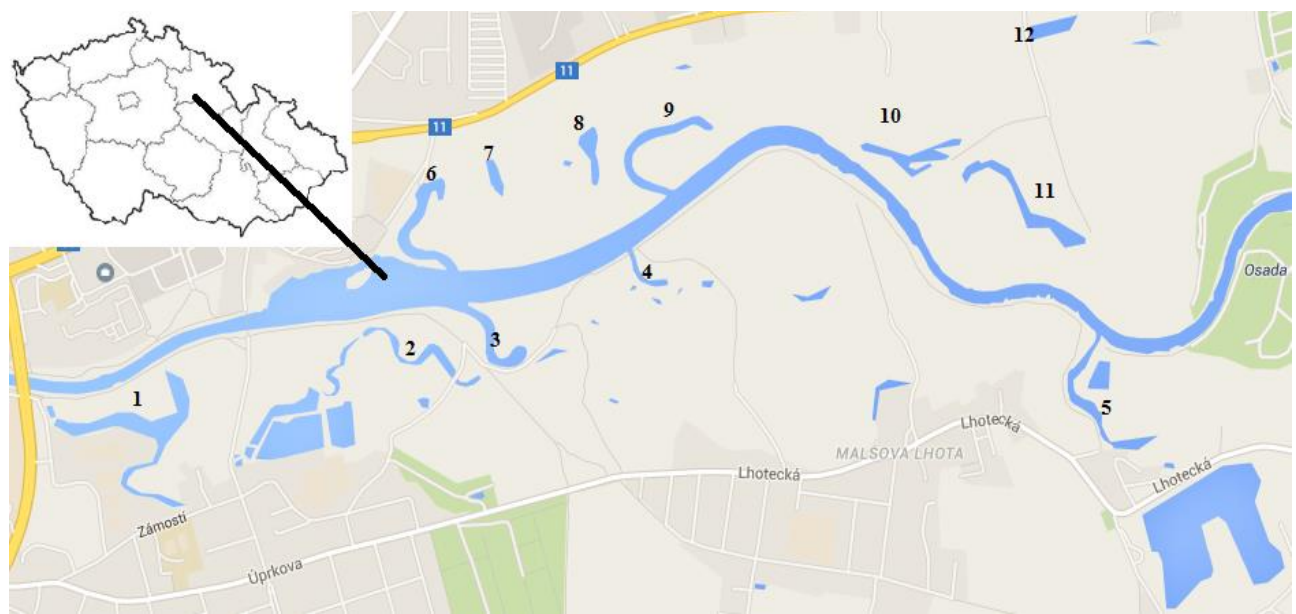

Key: Local names of study areas: 1 - Bejkovna, 2 - Jezuitská jezera, 3 - Sýkorky, 4 - Stará Orlice, 5 - Rameno u Stř́ibrného rybníka, 6 - Holštejn, 7 -V Lukách, 8 - Pekelská jezera, 9 - Kašparovo jezero, 10 -Hluboké jezero, 11 - Černé jezero, 12 - Pod auty. 
Vávra M.: Floodplain of the Orlice River (Eastern Bohemia, Czech Republic): the natural centre of biodiversity

\section{Natural characteristics}

The area belongs to the extensive geological unit of the Czech Basin. The main characteristic of the landscape of the channel of the conjoined Orlice River are river terraces, the result of erosion activity and also accumulation activity of the Quaternary streams. The altitude of the Nature Park falls between $230 \mathrm{~m}$ a.s.l by the confluence of the Orlice with the Elbe up to $500 \mathrm{~m}$ a.s.1. on the top levels of both channels. The river basin is relatively narrow in the upper reaches, just several tens of metres, while in the lower reaches the channel obviously widens and the landscape character changes from sub-montane towards distinctively lowland appearance with a number of preserved old river branches and scattered vegetation.

The study area is characterised by fluvisols or gley soils. Fluvisols form in proximity of rivers by deposition of particles (river and stream silt). The pedogenetic process is in natural segments regularly disturbed by the accumulation activity of the channel during floods. Under the non-distinctive leaf-mould horizon there is the parent substrate formed by sediments; the colour of the soil profile is brown to grey-brown. Granularity varies dependent of the speed of the stream and the distance from the riverbed. There is usually a layer of gravel by the base of the soil. The signs of gley processes are in the soil profile obvious relatively deep down. The percentage of leaf-mould is usually moderate, the soil tends to be slightly acidic or neutral, the soil is characterised by good absorption. Gley processes typically occur in gley soils. Under the shallow leaf-mould horizon there is clay gley horizon, permanently influenced by high level of the underground water. It was created by the reduction processes occurring by the permanent wetness and the presence of larger amount of organic materials. Sorption and physical qualities are permanently adverse (Tomášek, 2007).

The area of study belongs to the warm area and the warm climatic region $\mathrm{T} 2$ characterised by long and dry summer, very short temporary period with warm or mildly warm spring and autumn, short and mild, dry to very dry winter and short lasting of the snow cover (Quitt, 1971).

The average precipitation is $600-650 \mathrm{~mm}$ out of which $350-400 \mathrm{~mm}$ during the vegetation period (Fig. 2). The average air temperature reaches $8^{\circ} \mathrm{C}$, the average January temperature -2 to $-3^{\circ} \mathrm{C}$, while in July $18-19^{\circ} \mathrm{C}$ (Tolasz, 2007).

Fig. 2: Climatic condition of the study area

- gauge station Nový Hradec Králové, altitude of 278m a.s.1. (Czech Hydro-meteorological Institute)

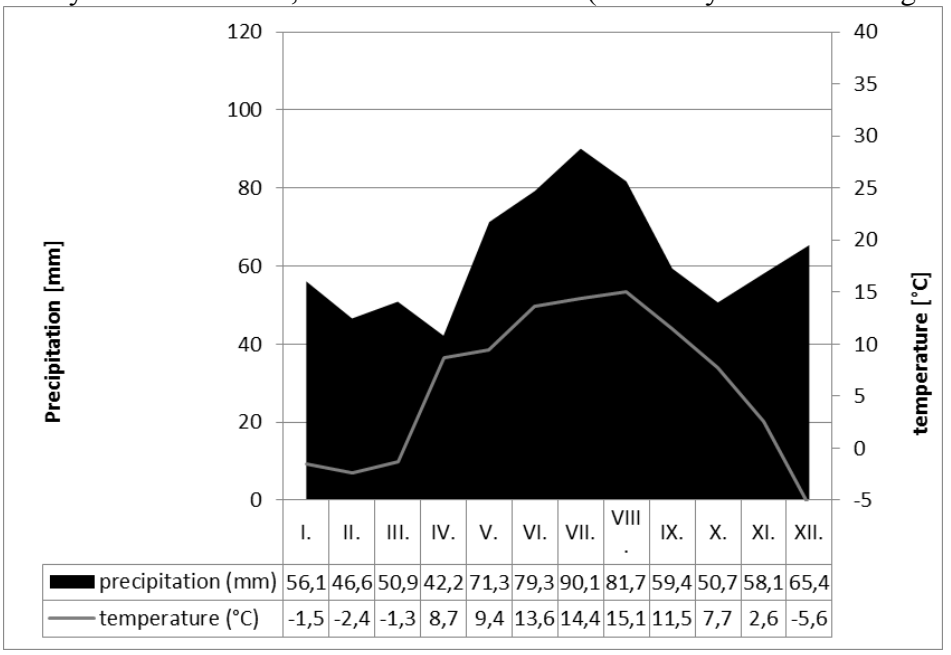


From the phyto-geographic point of view (Skalický, 1988) the study area belongs to the river basin of the Orlice River and to the phyto-geographical area of Thermophyticum, district of Czech thermophyticum (Thermobohemicum), region of East Elbe-area (Východní Polabí) and sub-region of Hradecké Polabí (15b). The vegetation of Hradecké Polabí is relatively diverse and dominated by mesophitic and thermophytic plants; the range of vegetation zones is planary to hilly, the relief of the landscape is flat to inclined; the dominant basis is formed by marlacious to sandy soils. The landscape is utilised for agriculture and has been modified by human influence.

Based on the map of the natural vegetation (Neuhäuslová et al., 1998) should the vegetation in the river basin of the Orlice River be left without further human influence, it would gradually change to bottomland forests (Alnion incanae), namely Pruno-Fraxinetum in the complex with Alnion glutinosae.

\section{Geomorphological development}

The slightly hilly area of the old city core of Hradec Králové, raising approximately $20 \mathrm{~m}$ above the confluence of both rivers, is the central point of the Pardubice Basin. It is remain of the gravel-sand terrace sedimented in older Quaternary Period by both rivers forming a typical river delta around the hilly parts. The River Elbe used to flow in five and the River Orlice in at least three separate channels. The confluences of individual branches of the rivers used to occur closer towards the channel of today's Elbe River. One of the channels of the today's Orlice River, later called the Umrlice River, used to flow to the Elbe far away from the city, near the current village of Třebeš. Due to its strategical position the hilly area has been colonised since the prehistoric times (Šámalová, 2007). The channel of the Orlice River in the late Tertiary headed toward south-east, that means towards the near-by bay of the Tertiary sea reaching to the Lanškroun and Ústi nad Orlici-areas. The proof of this are the valley sections of the channel as well as the terrace accumulations that were preserved in the eastern part of the catchment. The current catchment area of the Orlice River was formed after the end of Tertiary period by gradual drainage towards west and north-west. During the Pleistocene period, the catchment area of the Orlice River shifted from Chocen towards north (Rybár, 1989). The conjoined Orlice River belongs to the group of freely meandering streams. It forms a wide meandering channel in its basin where in the natural state. The channel can branch out to parallel river streams (Štěnička, 2006). The meandering arc itself is on the outer side formed by the so called concave river bank. The riverbed along the concave bank forms a pool, e.g. the deepest section in the cross-section of the stream, where the speed of the flow decreases and the character of the flow changes. During high flows is the concave bank rapidly worn away, gradually erodes and moves diagonally forward in the direction of the prevailing stream. The inner part of the riverbed - the so called convex river bank - is formed by gradually deposited sediments raising above the basic water level. These sediment heaps get increasingly covered by vegetation, first herbaceous, later by willow scrub (Salix sp.) and poplar (Populus nigra) forming the initial stage of the development of a natural bottomland forest in this area (Štěnička, 2006).

The geomorphological development of the conjoined Orlice River is nowadays influenced by human activity. In partial segments is the riverbed deadened in its development by stabilisation modifications (Fig. 3), in other parts it erodes wildly due to the disrupted equilibrum between the longitudinal slope and the resistance of the riverbed against erosion. The basic geomorphological and ecological problem of the stream in the entire valley river basin is the fact that due to the technical modifications of the whole riverbed of the conjoined River Orlice in the length of its depth erosion was deepened in some places by 1.5 to 3 metres comparing to its natural depth. This fact leads to the drainage of the entire river basin with 
Vávra M.: Floodplain of the Orlice River (Eastern Bohemia, Czech Republic): the natural centre of biodiversity

destructive impacts on aquatic and wetland ecosystems connected to the height of the level of the underground water and therefore to the dead-end river branches and pools (Štěnička, 2004).

Fig. 3: Regulated part of the stream in the built-up area of Hradec Králové (photo M. Vávra, 28. 4. 2014)

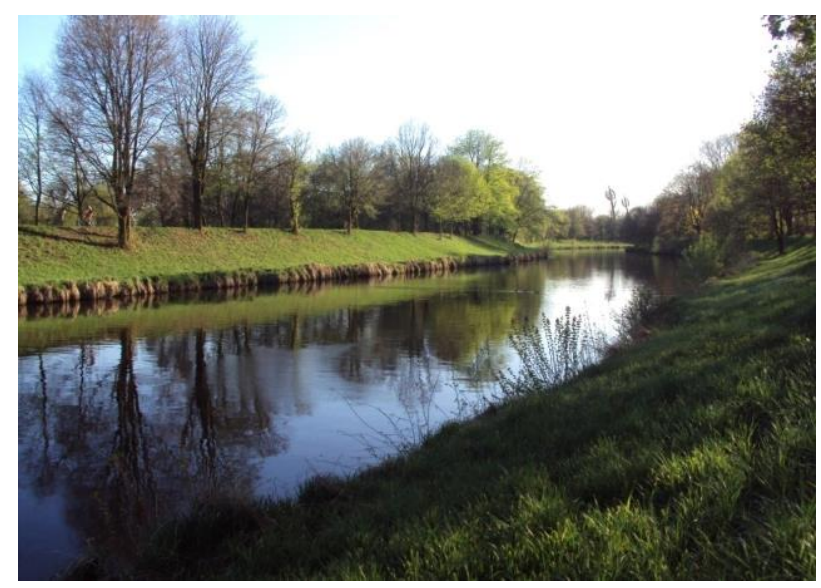

The Orlice River used to be a part of the baroque fort of the town of Hradce Králové. The emperor Joseph II. decided about the transformation of the town into an army fort in 1765 . The local conditions allowed the fort to be conveniently connected into the defence system, the so called manoeuvre with water and local rivers and streams. The works on the construction of the fort began in 1766 and included the demolition of extensive suburban areas, the residents of which had to move behind the protection zone of the fort. The space was meant to stay free even after suitable modifications (such as lowering of the terrain) and was intended to control flooding in case of emergency. New reinforced catchment areas were established for both, The Orlice and the Elbe Rivers - for the Elbe in the overall length of $1200 \mathrm{~m}$ and for the Orlice approximately $1600 \mathrm{~m}$. These took the role of the main defence moat. All original river branches were filled within the perimeter of the fort. The importance of defence moats decreased in the first half of the 19th century due to the progress in the development of army equipment.

The pressure to regulate the water conditions not just in the River Elbe was getting stronger in the second half of the $19^{\text {th }}$ century. The River Orlice, the largest tributary in the eastern part of Bohemia and possible to travel on by a raft, was becoming the centre of attention. The base for the project was a detailed geodetical measurement of the entire flood area and the fact that more than one thousand cross-sections of the channel were taken for the purposes of the proposed land improvement of the surrounding parcels of land. The regulation of the Orlice River was carried out gradually in seven phases from the confluence with the River Elbe to the weir in Svinary. The channel was fitted with both-sided embankments from the fortification walls to the end of the improvement. Penetration was carried out between 1.9 and 2.3 river kilometres forming a separated part of the steam on the left bank of the Orlice River. The locality is nowadays called Bejkovka or Bejčák. The side channel serves as a drive for the mill house in Malšovice; it was connected with a short infilling channel with the River Orlice. A new channel without lengthwise walls was built above the weir in 
Malšovice. Majority of the dead-end river branches were partially or fully infilled. New, leading barrages were formed across the inundation areas and were connected to the longitudinal embankments. Their purpose was to concentrate the spilt flood waters back into the capacity channel. The barrages were re-constructed in the thirties. Following the floods in 1997, the embankments were increased and the system was fitted with other structures in order to be dimensioned to protect against the so called hundred year flow $\left(\mathrm{Q}_{100}\right)$ (Š́malová, 2007).

\section{Methods}

The research on pools and the dead-end river branches was carried out throughout the vegetation season in 2012-2013 and a part of vegetation season in 2014 (spring and summer aspect). Botanical inventarisation of vascular plants occurring in pools, dead-end river branches, as well as the adjacent shore communities and ecotonal communities was conducted in all localities. The survey of aquatic macrophytes was carried out from a boat. Species were identified and the nomenclature from the Vegetation Key for the Czech Republic (Kubát et al., 2002) was used. Protected and endangered taxons were filed based on the Red List of vascular plants of the Czech Republic (Grulich, 2012), regulation 395/1992 Coll., as amended by later regulations and based on the List of extinct, lost and endangered taxons of vascular plants in the area of East Bohemia (Faltys, 1993). The nomenclature was united based on the List of vascular vegetation of the Czech Republic (Danihelka et al,. 2012). The Google.cz portal was utilised for the purposes of the topographic delimitation (available at www.google.cz/maps). The Climagraph (Fig. 2) is created based on the methods of Walter (Slavíková, 1986). Phyto-coenologic survey was produced based on Braun-Blaquet nine tier scale of abundance and dominance for each locality (Prach, 1985). The studied ecosystems were allocated to vegetation units (Chytrý et al., 2010) and further distinguished to phyto-coenoses (Chytrý et al., 2011). The phyto-coenose surveys were subjected to the databases programme TURBOVEG (Hennekens et Schaminée, 2001), the basic software of the Czech national phytocoenologic database. Further analysis of phyto-coenologic survey results saved in the programme of TURBOVEG was carried out in the programme Juice (Tichý, 2002), dividing the survey results into related phytocoenoses. The Red List of vascular plants of the Czech Republic was used to categorise to which level were rare plants endangered (Grulich, 2012):

$\mathrm{C} 1$ - critically endangered species, C2 - strongly endangered species, C3 - endangered species, $\mathrm{C} 4 \mathrm{a}$ - rarer taxons requiring further attention - known status, $\mathrm{C} 4 \mathrm{~b}$ - rarer taxon requiring further attention - unknown status.

Critically endangered species (C1) and strongly endangered species (C2) are also listed with the reason of endangerment.

The following categories are used:

$\mathbf{r}$ - rarity: critically endangered species (C1) occurs on $1-5$ localities or strongly endangered species (C2) occurs on $6-20$ localities. The populations are more or less stable; recently do not decline and were not declining rapidly in the past

$\mathbf{t}$ - trend: in the category of critically endangered species (C1) it is expected that the population will decline on at least $90 \%$ of historical localities; in the category of strongly endangered species (C2) it is expected on 50-90\%. The decline of majority of species, mainly the taxons with difficult spreading, new discoveries on localities are not a part of the count, if the localities were not studied in detail in the past - it can be expected that those species occurred there in the past, too. 
Vávra M.: Floodplain of the Orlice River (Eastern Bohemia, Czech Republic): the natural centre of biodiversity

$\mathrm{b}-\mathrm{a}$ combination of rarity and trend: the taxon fulfils the condition of rarity in a certain category or slightly exceeds is but at the same time it became extinct on some localities and its population decreased dramatically. A reason for this classification can also be poor regeneration in long-lived woody species even providing the condition of current populations is relatively good (http://botany.cz/cs/cerveny-seznam/).

The regulation 395/1992 Coll, as amended:

$\S 1$ - critically endangered species, $\S 2$ - strongly endangered species, $\S 3$ - endangered species.

Rare taxons in the area of Eastern Bohemia were identified based on the List of extinct, lost and endangered taxons of vascular vegetation in the area of Eastern Bohemia (Faltys, 1993)

$\mathrm{C} 1$ - critically endangered species, C2 - strongly endangered species, C3 - endangered species, C4 - potentially endangered or rare species, monitored.

Categorisation of invasive species was united based on the publication of Catalogue of alien plants of the Czech Republic (2nd edition): checklist update, taxonomic diversity and invasion patterns (Pyšek et al., 2012).

\section{RESULTS}

The total of 449 taxons of vascular plants were recorded during the botanical inventarisation on dead-end river branches and pools of the Orlice River in the section from Hradec Králové to Malšova Lhota. The richest locality from the biodiversity point of view was Holštejn, while the poorest one was Sýkorky utilised anthropically as a marina. The dead-end river branches and pools in the river basin of the Orlice River are rich in specially protected and rare plant species. The total of 68 taxons of vascular plants, named in the Red List of vascular plants in the Czech Republic (Grulich et al., 2012) and protected under the Regulation 395/1992 Coll as amended or listed in the Red List of Eastern Bohemia (Faltys, 1993), were found in the mapped localities. The following species belong among the specially protected species of the study area: Allium angulosum ( 22$)$, Galanthus nivalis $(\S 3)$, Hottonia palustris (§3), Leucojum vernum (§3), Lysimachia thyrsiflora (§2), Nymphaea alba (\$2), Potamogeton alpinus (\$2), Potamogeton praelongus (\$1) and Taxus baccata $(\S 2)$. In the case of Galanthus nivalis, Leucojum vernum, and likely also Nymphaea alba and Taxus baccata, their occurrence is secondary. Out of the 55 taxons named in the Red List of vascular plants of the Czech Republic, two critically endangered taxons can be found in the study area (Potamogeton praelongus, Nymphaea alba), as well as six strongly endangered taxons (Carex elata subsp. elata, Hydrocharis morsus - ranae, Potamogeton alpinus, Potamogeton perfoliatus, Sium latifolium and Stellaria palustris) and twenty taxons in danger of extinction (e.g. Allium angulosum, Barbarea stricta, Batrachium circinatum, Cardamine dentata, Cyperus fuscus, Epilobium parviflorum, Hottonia palustris, Hydrocharis morsus-ranae, Leersia oryzoides, Lemna trisulca, Lysimachia thyrsiflora, Potamogeton acutifolius, Potamogeton lucens, Potamogeton obtusifolius, Thalictrum lucidum and Veronica maritima).

The specially protected and critically endangered species of Stratiotes aloides $(\S 1)$ was not recorded unlike in the past surveys.

The total of 57 rare taxons from the regional Red List (Faltys, 1993) were recorded in the area of Eastern Bohemia. There are 85 geographically introduced species (naturalised, growing wild or invasive) were recorded in the study area. Out of these 22 display invasive behaviour (Pyšek et al., 2012). The most dangerous invasive species in the dead-end river 
branches and pools include Acer negundo, Impatiens glandulifera, Impatiens parviflora, Populus x canadensis, Quercus rubra, Reynoutria japonica, Robinia pseudoacacia, Solidago canadensis and Solidago gigantea. The largest number of invasive species were recorded on the locality Bejkovna (Fig. 1) that is the closest one to the built-up area of Hradec Králové. On the other hand, the lowest number of invasive species was recorded on the isolated localities of Stará Orlice and V Lukách (both localities contained three species). It is; therefore, possible to conclude that the localities of Stará Orlice and V Lukách are both relatively ecologically stable.

Fig. 4: Comparison of species diversity and numbers of rare and invasive species on the studied localities in the river basin of the Orlice River by Hradec Králové

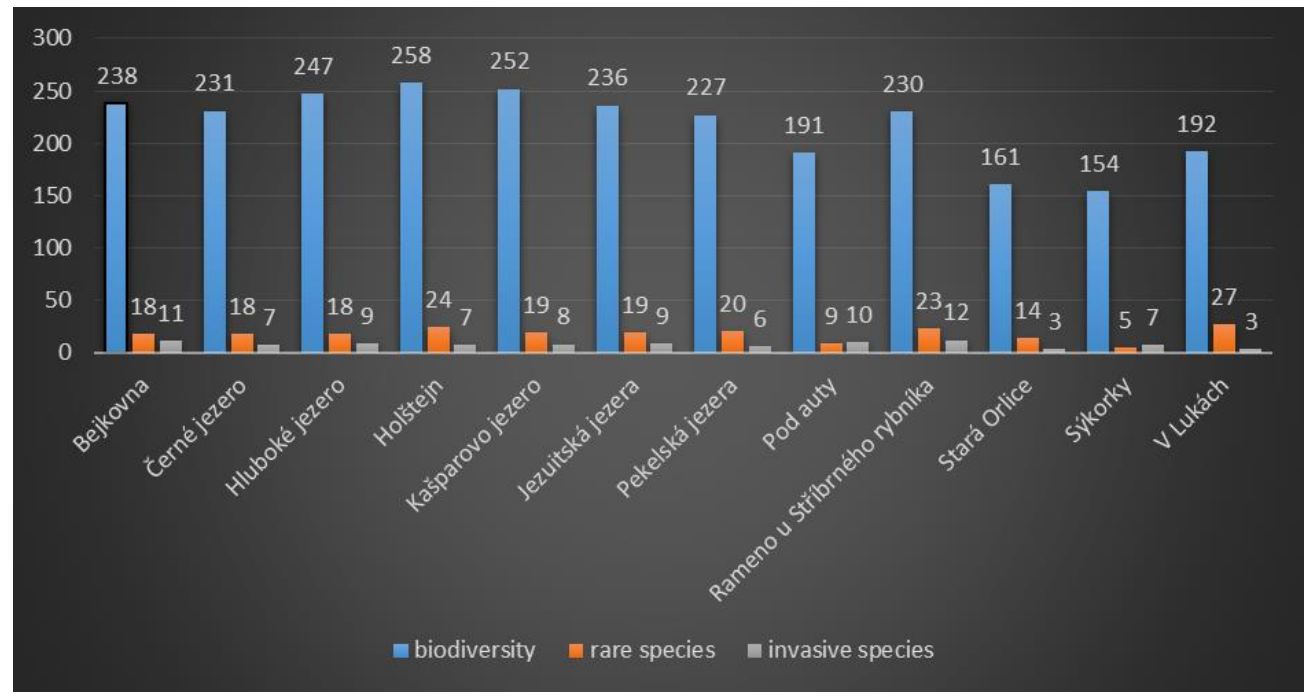

The biodiversity-wise most important localities from the number of species point of view are Bejkovna, Holštejn and Kašparovo jezero, while from the rarity of the occurring communities point of view it's Rameno by Strríbrný rybník and V Lukách (Fig. 4). The Bejkovka locality is an interesting example of rare vegetation communities of aquatic and wetland plants forming in the built-up area of towns and cities under the current non-intrusive management. Localities of Holštejn and Kašparovo jezero are large dead-end river branches with filled zones often flooded during high water levels that undergo transport of diaspores of numerous precious taxons of plants. Examples of plants growing there include: Cicuta virosa, Lysimachia thyrsiflora, Sium latifolium or Stellaria palustris. The adjacent meadows are mown twice a year. An overall revitalisation of the locality will be necessary for the survival of Potamogeton praelongus in the locality of Rameno by Strríbrný rybník. The revitalisation will include removal of sediments and reconstruction of shore vegetation. The locality of V Lukách is an isolated pool with good quality communities of Hydrocharis morsus - ranae, Hottonia palustris, Lysimachia thyrsiflora, Potamogeton obtusifolius, Sium latifolium or Utricularia autralis. The occurrence of Stratiotes aloides was not confirmed there, despite occurring in the previous years.

The following vegetation units were distinguished according to the characteristics of Chytrý (Chytrý et al., 2011) based on the overall phyto-coenologic table. Communities of Nymphaeion albae Oberdorfer 1957 occur in the study area of the river basin of the Orlice River by Hradec Králové. It is a community of rooted plants with floating leaves on the 
Vávra M.: Floodplain of the Orlice River (Eastern Bohemia, Czech Republic): the natural centre of biodiversity

surface of stagnant waters, of the association of Nymphaeo albae - Nupharetum luteae Nowiński (1927). The dominant species is Nuphar lutea. There are mainly small pleustophytes in the floating zone (e.g. Lemna minor, Spirodela polyrhiza). The submerged zone tends to be supressed in the communities with a large coverage of yellow water lily due to the lack of light under the water surface. The association is a natural vegetation of mesotrophic and eutrophic waters in the river basins of lowland rivers. In well-developed vegetation cover localities the management type is non-intrusive. Sometimes it is necessary to remove the layer of sediment and renew the flow-through ability of waterbodies. The main risk is cause by river regulations (lack of natural floods and periods of drying out), vegetation eating fisheries and water fowl, use of herbicides and strong eutrophication of the habitat.

The association of Potamion: Potamo pectinati - Myriophylletum spicati Rivas Goday 1964 is also represented there. It is the vegetation type of Myriophyllum spicatum. Myriophyllum spicatum is known for wide ecological amplitude and that is why this vegetation can occur in various types of waters; however, it prefers localities with regular mechanical disturbance or in the early succession stages. The association tolerates even slightly murky waters. This vegetation occurs in the locality of Bejkovna where the vegetation is disturbed by the flow of the Orlice River. The association does not require any protection.

The association of Potametum praelongi Hild 1959 can be found in the temporary protected area of Rameno by Stř́brný rybník. The diagnostic species is Potamogeton praelongus. This type of vegetation is in the Czech Republic very rare and associated with calmer stretches of rivers and dead-end river branches. It is very likely that in the environment with high levels of nutrients this association cannot exist long-term. Potametum praelongi is characteristic mainly in the waters of cooler regions, it is of a relict character in the Czech Republic. The locality of Rameno by Stříbrný rybník is of a great importance for the flora of Eastern Bohemia as well as for the vegetation of the Czech Republic itself from the species protection point of view. It is the last locality of natural occurrence of the critically endangered Potamogeton praelongus in the Czech Republic. There were approximately 100,000 stems of Potamogeton praelongus estimated on the last but one locality in Jezuitska jezera (Fig. 1) in Malšovice by Hradec Králové in 1987, but in the next two years virtually all of the population dies due to the eutrophication of the pool. In December 2001there was an extensive removal of mud in the river branch by the so called dry method. The shore vegetation was thinned in 2002 in order to allow more light into the locality and to lower the amount of organic waste. After the rescue programme in the dead-end river branch of the Elbe river basin was agreed by the Ministry of Environment, the responsible state organisation applied for funds from the Programme for Landscape Management. The funds were to be used to remove part of the deposited mud with a suction machinery. Exceptions from the protection of Potamogeton praelongus and Potamogeton alpinus were obtained together with the content of all land owners in the area and a new flood management was produced. The mud removal started in the second half of August 2003 in the section that were the most affected by the deposits. The vital colonies of both Potamogeton species were marked with poles prior to the start of the works. Individual plants were removed from the localities potentially directly affected by the suction machinery. The plants were then stored in containers and kept in ponds of the fishery association in Malšovice in Hradec Králové. Once the works were completed, individual plants were planted back to their original locality. The waterlogged sediment was temporarily stored on adjacent land and later taken away (Prausová et al., 2004). Genetic analyses and tests of germination from samples of leaves from the current micro-populations of Potamogeton praelongus were carried out between 2009 and 2010 with the financial help of EHP and 
Norway under the project called „Rescue of Potamogeton praelongus “. A sedimentation tank was created where the Silver Brook (Stríbrný potok) enters the locality in order to prevent changes to the trophical levels of the survey area. It is intended to carry out the removal of mud and sediments from the entire river branch in the future. Collection of waste water from the near-by recreation chalets also needs to be resolved. A large problem is currently caused by ducks pecking on the endangered plants. This problem occurred by the end of the vegetation season of 2012 and the population in Natural Protected Area of Rameno by Stříbrný rybníka was negatively affected in 2013. In case the realisation of the rescue programme is successful, a change in the conservation management in the locality of Rameno by Stríbrný rybníka from the current temporary protected area to a small scale protected area (www.zachranneprogramy.cz), (Prausová et al., 2010). Another rare association is represented by Potametum tenuifolii Kiprijanova et Laščinskij (2000). It is the vegetation of shallow waters with Potamogeton alpinus. This vegetation can be found in the temporarily protected area and does not require immediate protection. It belongs to the communities of aquatic habitats in late stages of succession development and often forms a mosaic with successively further levels of vegetation, such as reed bed, vegetation of tall rushes etc. The largest risk for this vegetation type is represented by eutrophication of water habitats. Potamogeton alpinus is less sensitive to mechanical disturbance. That is a great advantage during conservation management; however, the basic condition for the continual occurrence of these communities is preservation of wetland localities with clean water.

The Potametum crispi von Soó (1927) association is known at the locality Pod auty. Potamogeton crispus is the main dominant species of the association. It has a wide ecological amplitude and does not require any conservation management. The vegetation enters the period of lower activity during high temperatures and is not restricted by mowing. Mowing the vegetation in aquatic environment can actually support diaspore production.

Another association is represented by Lemnion minoris de Bolós et Masclans (1955) and includes communities of aquatic vegetation not rooted in the substrate, known as pleustophores. The association of Lemnetum minoris von Soó (1927) occurs at the localities of Černé and Hluboké jezero. Lemnion minoris is the dominant species; it often forms a full vegetation cover on the surface of the aquatic habitat. The vegetation cover avoids lakes with strong influence of wind of waves. Landscape eutrophication supports the development of this association. Easy regeneration and fast growth is a great advantage for spreading in more shallow waters. This type of vegetation is often necessary to be regulated during the conservation of more rare aquatic species or during fish management.

The association of Lemnetum trisulcae den Hartog (1963) can also be found at Černé jezero. The dominant species is submerged Lemna trisulcis, other species include Lemna minor and submerged plants anchored to the substrate such as Ceratophyllum demersum. This type of vegetation often occurs periodically, suitable conditions for growth do not occur annually. The vegetation does not require any conservation management, suitable conditions depend on lower water levels. The water levels at Černé jezero are subject to natural fluctuations and the community thrives there.

The pool „V Lukách“ contains alliances of Hydrocharition morsus - ranae (Passarge, 1964) Westhoff et den Held (1969) -with the association of Hydrocharitetum morsus - ranae van Langendonck (1935). The community represents natural vegetation of shallow stagnant waters in later phase of sedimentation. It follows the succession development of shallow waters communities with dominance of plants anchored to the substrate. Further development leads to various types of reed beds and communities of tall rushes, often containing Hydrocharis morsus-ranae as a part of the mosaic. This is also the case with the vegetation in this isolated pool; it is a rare locality with developed vegetation of Hydrocharis 
Vávra M.: Floodplain of the Orlice River (Eastern Bohemia, Czech Republic): the natural centre of biodiversity

morsus - ranae within the entire study area. Management is usually non-intrusive, restriction of reed beds is often suitable due to the fact that they speed up the succession process.

This pool also contains alliances of Utricularion vulgaris Passarge (1964) - association of Utricularietum australis Müller et Görs (1960) with the diagnostic species of Utricularia australis. The locality is subject to sedimentation leading to premature summer drying. The population therefore fluctuates naturally. Management includes mainly protection from degradation of the locality, individually to some extent in removal of sediments.

The middle section of the localities of V Lukách and Pekelská jezera tend to grow over with communities of Ranunculion aquatilis Passarge (1964) alliance of Potamo - perfoliati with the association of Ranunculetum circinati Sauer (1937). The habitats are formed by the parts of the pools that are fully open to sun light, with the dominant Batrachium circinatum, together with species such as Lemna trisulca, Myriophyllum spicatum or Potamogeton crispus. No management is required for these communities.

The shore vegetation often includes the alliance of Phalaridion arundinaceae Kopecký (1961) with the association of Caricetum buekii Hejný et Kopecký (1965). It is formed by tall vegetation types and occurs naturally in the sediments on streams or secondary following the removal of willow and alder scrub. It tends to make room for more shade loving vegetation in the succession development process.

Another alliance, the Magno - Caricion gracilis Géhu (1961) with association of Caricetum acutiformis Eggler (1933) also occurs there. This vegetation forms in the late stages of sedimentation in shallow waters. It follows reed beds and vegetation of tall rushes with optimal existence in deeper water in the succession development. Negative impacts on species composition can be lessened by mowing with the interval of several years and by removal of the biomass from the particular locality.

Further communities on the conjoined Orlice River include Magno-Caricion gracilis Géhu (1961), association: Caricetum gracilis Savič (1926). It is the natural vegetation of the succession phase when sedimentation of fresh water wetlands often occurs. This vegetation follows reed beds in succession. There are only species poor communities preserved nowadays, due to the intensive agriculture. This vegetation does not require any additional management on flooded localities. It often declines during strong applications of herbicides or during the lack of flood events.

The community of Phragmition australis Koch (1926) with the association of Typhetum latifoliae Nowiński (1930) occurs at the locality Pod auty. It includes reed beds with the dominance of Typha latifolia and forms a natural step of shallow waters succession. More species rich communities sometimes require mowing and biomass removal.

A more common association is the Phragmitetum australis Savič (1926). It is vegetation with common reed, high percentage of mature vegetation and a wide ecological amplitude. It occupies wetlands of various trophic situation and various levels of $\mathrm{pH}$ of the substrate. Its optimum lies in mesotrophic to naturally eutrophic environments, on slightly acidic to basic substrates containing calcium and low levels of organic acids, ions of $\mathrm{Fe}^{2+}$ and hydrogen sulphide. The vegetation can form a long-term stable succession stage. A full or long-term lack of management is undesirable. Based on the local conditions, it is possible to utilise regular mowing with biomass removal (reduction in accumulation of old vegetation) or a combination of mowing and burning of the old vegetation outside of the vegetation period.

The association of Glycerietum maximae Nowiński (1930); corr. Šumberová, Chytrý et Danihelka in Chytrý (2011) hoc loco is also present. It is the natural part of the succession series during sedimentation in aquatic habitats. This vegetation is connected to wetlands in late phase of succession and represents the transformation from pioneer reed beds to the vegetation of tall rushes. It usually does not require any conservation management. 
Fig. 5: Lysimachia thyrsiflora, a specially protected species, found more recently

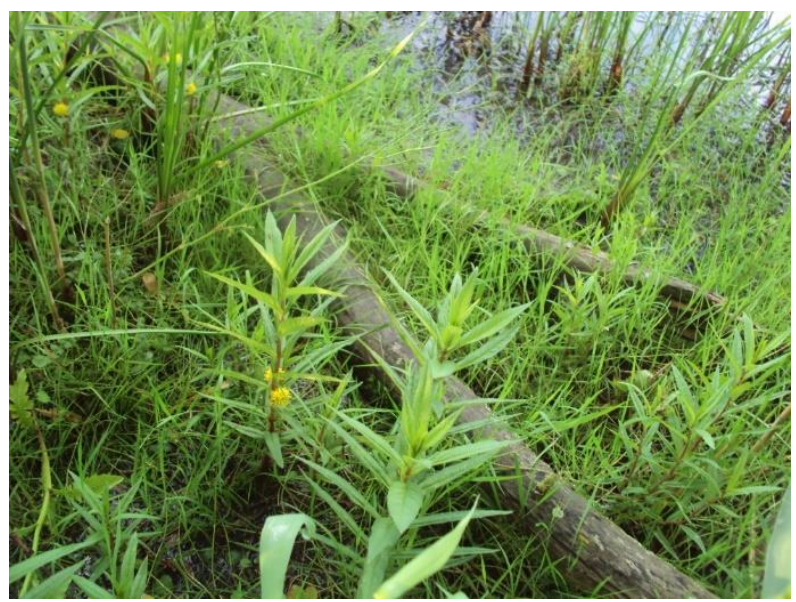

Table 1: List of vegetation units found in the study area

\begin{tabular}{|c|c|}
\hline Alliance & Association \\
\hline Nymphaeion albae & Nymphaeo albae - Nupharetum luteae \\
\hline \multirow{4}{*}{ Potamion } & Potamo pectinati - Myriophylletum spicati \\
\hline & Potametum praelongi \\
\hline & Potametum tenuifolii \\
\hline & Potametum crispi \\
\hline \multirow{2}{*}{ Lemnion minoris } & Lemnetum minoris \\
\hline & Lemnetum trisulcae \\
\hline Hydrocharition morsus - ranae & Hydrocharitetum morsus - ranae \\
\hline Utricularion vulgaris & Utricularietum australis \\
\hline Ranunculion aquatilis & Potamo-perfoliati - Ranunculetum circinati \\
\hline Phalaridion arundinaceae & Caricetum buekii \\
\hline \multirow{2}{*}{ Magno - Caricion gracilis } & Caricetum acutiformis \\
\hline & Caricetum gracilis \\
\hline \multirow{3}{*}{ Phragmition australis } & Typhetum latifoliae \\
\hline & Phragmitetum australis \\
\hline & Glycerietum maximae \\
\hline
\end{tabular}


Vávra M.: Floodplain of the Orlice River (Eastern Bohemia, Czech Republic): the natural centre of biodiversity

Table 2: Comparison of botanical findings in the study area of the River Orlice

\begin{tabular}{|c|c|c|c|c|c|c|c|c|c|c|c|}
\hline 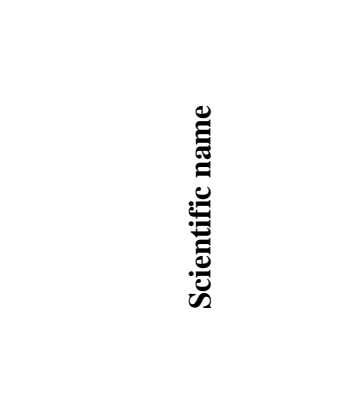 & 罗 & 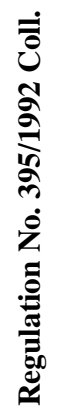 & 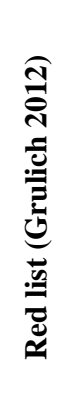 & 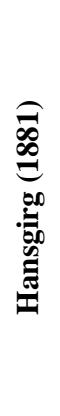 & 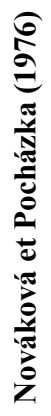 & 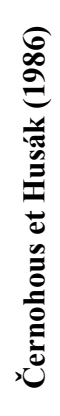 & 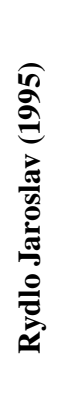 & 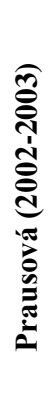 & 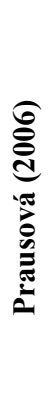 & 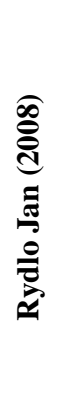 & 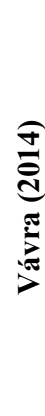 \\
\hline Allium angulosum & - & $\S 2$ & $\mathrm{C} 3$ & $\checkmark$ & - & - & - & $\checkmark$ & - & - & $\checkmark$ \\
\hline Barbarea stricta & - & - & $\mathrm{C} 3$ & $\checkmark$ & - & - & - & - & $\checkmark$ & - & $\checkmark$ \\
\hline Batrachium circinatum & - & - & $\mathrm{C} 3$ & - & $\checkmark$ & - & - & $\checkmark$ & - & $\checkmark$ & $\checkmark$ \\
\hline Cardamine dentata & - & - & $\mathrm{C} 3$ & $\checkmark$ & - & - & - & - & $\checkmark$ & - & $\checkmark$ \\
\hline Carex elata & $\mathrm{LC}$ & - & $\mathrm{C} 2 \mathrm{t}$ & - & - & - & - & - & - & - & $\checkmark$ \\
\hline Cicuta virosa & $\mathrm{LC}$ & - & $\mathrm{C} 2 \mathrm{~b}$ & $\checkmark$ & - & - & - & - & - & - & $\checkmark$ \\
\hline Cyperus fuscus & $\mathrm{LC}$ & - & $\mathrm{C} 3$ & - & $\checkmark$ & - & - & - & - & - & $\checkmark$ \\
\hline Epilobium parviflorum & $\mathrm{LC}$ & - & $\mathrm{C} 3$ & - & - & - & - & - & - & - & $\checkmark$ \\
\hline Hottonia palustris & $\mathrm{LC}$ & $\S 3$ & $\mathrm{C} 3$ & $\checkmark$ & - & - & - & $\checkmark$ & $\checkmark$ & $\checkmark$ & $\checkmark$ \\
\hline Hydrocharis morsus-ranae & $\mathrm{LC}$ & - & $\mathrm{C} 2 \mathrm{~b}$ & $\checkmark$ & $\checkmark$ & $\checkmark$ & $\checkmark$ & - & $\checkmark$ & - & $\checkmark$ \\
\hline Leersia oryzoides & - & - & $\mathrm{C} 3$ & $\checkmark$ & $\checkmark$ & - & - & - & - & $\checkmark$ & $\checkmark$ \\
\hline Lemna trisulca & $\mathrm{LC}$ & - & $\mathrm{C} 3$ & $\checkmark$ & - & $\checkmark$ & - & $\checkmark$ & $\checkmark$ & $\checkmark$ & $\checkmark$ \\
\hline Lysimachia thyrsiflora & - & $\S 2$ & $\mathrm{C} 3$ & - & - & - & - & - & $\checkmark$ & - & $\checkmark$ \\
\hline Nymphaea alba & $\mathrm{LC}$ & $\S 2$ & $\mathrm{C} 1 \mathrm{t}$ & - & - & $\checkmark$ & - & - & - & $\checkmark$ & $\checkmark$ \\
\hline Potamogeton acutifolius & - & - & $\mathrm{C} 3$ & $\checkmark$ & - & $\checkmark$ & - & - & $\checkmark$ & $\checkmark$ & $\checkmark$ \\
\hline Potamogeton alpinus & $\mathrm{LC}$ & $\S 2$ & $\mathrm{C} 2 \mathrm{~b}$ & $\checkmark$ & - & - & $\checkmark$ & $\checkmark$ & - & $\checkmark$ & $\checkmark$ \\
\hline Potamogeton lucens & $\mathrm{LC}$ & - & $\mathrm{C} 3$ & $\checkmark$ & $\checkmark$ & - & - & - & - & - & $\checkmark$ \\
\hline Potamogeton obtusifolius & $\mathrm{LC}$ & - & $\mathrm{C} 3$ & $\checkmark$ & - & - & - & - & $\checkmark$ & $\checkmark$ & $\checkmark$ \\
\hline Potamogeton perfoliatus & $\mathrm{LC}$ & - & $\mathrm{C} 2 \mathrm{t}$ & $\checkmark$ & - & - & - & - & - & - & $\checkmark$ \\
\hline Potamogeton praelongus & $\mathrm{LC}$ & $\S 1$ & $\mathrm{C} 1 \mathrm{t}$ & - & $\checkmark$ & $\checkmark$ & $\checkmark$ & $\checkmark$ & - & $\checkmark$ & $\checkmark$ \\
\hline Sium latifolium & - & - & $\mathrm{C} 2 \mathrm{~b}$ & $\checkmark$ & - & - & - & $\checkmark$ & $\checkmark$ & $\checkmark$ & $\checkmark$ \\
\hline Stratiotes aloides & $\mathrm{LC}$ & $\S 1$ & $\mathrm{C} 1 \mathrm{t}$ & $\checkmark$ & $\checkmark$ & $\checkmark$ & - & - & $\checkmark$ & - & - \\
\hline Stellaria palustris & - & - & $\mathrm{C} 2 \mathrm{~b}$ & $\checkmark$ & - & - & - & - & $\checkmark$ & - & $\checkmark$ \\
\hline Thalictrum lucidum & - & - & $\mathrm{C} 3$ & $\checkmark$ & - & - & - & $\checkmark$ & $\checkmark$ & - & $\checkmark$ \\
\hline Veronica maritima & - & - & $\mathrm{C} 3$ & $\checkmark$ & - & - & - & $\checkmark$ & $\checkmark$ & - & $\checkmark$ \\
\hline
\end{tabular}

Key: LC - least concern species; Red list - Red List of vascular plants of the Czech Republic; categories of the level of endangerment - see Methods. 


\section{DISCUSSION}

It is good to see that the dead-end river branches and pools by the regulated section of the channel of the conjoined Orlice River remain natural refugia of aquatic and wetland vegetation. One of the oldest sources of information on the vegetation of the city of Hradec Králové is the Vegetation of the surroundings of Hradec Králové (1881); however, the locations of findings are not accurately specified.

Macrophytic vegetation of Eastern Bohemia was in 1970-1978 studied by Černohous and Husák (Černohous et Husák, 1986); the results of their study in this area indicated the richness of aquatic and wetland vegetation due to the high diversity of aquatic biotopes. Even then they pointed out that economic pressures on intense fisheries management and duck keeping together with agricultural land improvements led to the decrease of aquatic habitat diversity and the diversity of macrophytic vegetation, mainly oligotrophic and mesotrophic species (a good example is the extinction of the community of Potametum colorati or the decrease of Potametum alpini). On the other hand, communities thriving in higher trophic level of the environment are on the increase, as proven in works from the Czech Republic as well as from abroad (e.g. Haslam, 1978; Werie et Jorga, 1981; Prach et al., 1990) and that is regardless on their geographical location which can lead to spreading of invasive species (e.g. McDonald, 1988; Rydlo, 1995).

Rare vegetation communities are connected to localities with only small economic potential, such as the dead-end river branches (Černohous et Husák, 1986). This is confirmed for example by strongly endangered species of Potamogeton alpinus remaining in the study area of the river basin of the Orlice River by Hradec Králové only in the temporary protected area of Rameno by Stríbrný rybník. Černohous a Husák prove on the example of the pool from the surroundings of Hradec Králove the presence of the following taxons: Hydrocharis morsus - ranae, Nymphaea alba, Potamogeton praelongus or Stratiotes aloides. Survey of the distribution of Stratiotes aloides in the lower reaches of the Orlice River was also carried out by F. Černohous (Černohous, 1981). It used to be a common species until the eighties, but started to decrease without any known reason thereafter (Rydlo, 2008). It is possible to speculate over the changes in the trophical levels of waters (Abeli et al., 2014) or on the impact of the presence of sulphur from the growing deposition of ashes from communal energy sources (Smolders et al., 2003). Stratiotes aloides was introduced in the Czech Republic and probably already disappeared from this part of the river basin already; it has not been confirmed in any of the studied pools since the year of mapping for the Natura 2000 network (Prausová, 2003). A speculation about the disappearance of this obvious species is captured in Rydlo (2008).

It is necessary to mention that there is a regional Red List of Eastern Bohemia (Faltys, 1993), when we are judging the rarity of individual species. At the time of the creation of the List, the rarest taxons appeared to be Nymphaea alba, Potamogeton alpinus and Potamogeton praelongus that were classified as critically endangered. Strongly endangered were Allium angulosum, Lysimachia thyrsiflora, Stratiotes aloides or Thalicthrum lucidum.

Jaroslav Rydlo (Rydlo, 1995) in his work in 1984-1994 studied the representation of macrophytes in regulated as well as non-regulated parts of the conjoined Orlice River. Survey from a boat, during which he was listing presence or absence of individual species, estimated the size of vegetation communities on a three-level scale and showed that in the regulated part of the channel by Hradec Králové the representation of the majority of macrophytic species significantly decreased.

Kopecký (Kopecký, 1967) listed species such as Acorus calamus, Butomus umbellatus, Glyceria maxima, Hydrocharis morsus-ranae and Potamogeton natans growing at the beginning of the channel in 1964. Hydrocharis morsus - ranae was already missing in 1984, 
Vávra M.: Floodplain of the Orlice River (Eastern Bohemia, Czech Republic): the natural centre of biodiversity

while the other species still occurred there; a new species to the list was Nuphar lutea. By 1994 all of these species disappeared. Big changes in the species composition were also recorded in the regulated part of the channel by Hradec Králové in the past. Out of the species recorded here completely disappeared Potamogeton crispus and Stratiotes aloides, while the number of localities of the following species: Acorus calamus, Butomus umbellatus, Ceratophyllum demersum, Potamogeton natans or Sparganium erectum significantly decreased (Rydlo, 1995). The geographically introduced species of Acorus calamus was confirmed even on seven out of twelve monitored localities, although potentially endangered species of Butomus umbellatus was recorded only in four pools within the study of the dead-end river branches. Potamogeton crispus is in the Orlice River pools found often, it is the dominant species on localities not suitable for others species due to its wide ecological amplitude. Localities affected by human influences, such as commercial fishery, are often preferred.

Glyceria maxima is a common part of the reed beds, the vegetation spreads more due to eutrophisation and quick aging of the seeds. The strongly endangered Hydrocharis morsus ranae can only long-term thrive in the pool opposite the bakery of Hradec Králové (locality V Lukách) where the vegetation cover significantly increased in 2012-2015 and the population is regarded stable there.

With the exception of Potamogeton natans and Stratiotes aloides, all other above mentioned species were confirmed in the area of interest. The diversity of the pools and the dead-end river branches of the Orlice River is high, while the communities of species of aquatic macrophytes are very limited in the deep, flowing water in the regulated part of the channel containing two weirs. The environment here is rather uniform.

The reason for lowering of the species diversity is apart from the habitat fragmentation and high level of shading (Merritt et al., 2010) also irregular dynamics in the often murky water column (e.g. Kovář, 1983; 1996). The dynamics are often accompanied by disturbances during artificial lowering and increasing of the water levels (e.g. Drinkard et al., 2011). Rather common are communities with Nuphar lutea or Ceratophyllum demersum in the sections of stone embankment serving as a stabilisation element of the channel as well as near dead-end river branches or banks of the channel. Comparing to the past, communities of the alliance of Phragmition australis forming large vegetation cover in the sections of slow flowing water are still characteristic here. Vegetation of rivers and vegetation of dead-end river branches vary considerably, both quality and quantity-wise. There are many species and communities in the dead-end river branches and pools that do not exist in the river. Rydlo jun. (Rydlo, 2008) noted several communities, such as Ranunculetum fluitantis, Nasturtietum officinalis and Fontinalietum antipyreticae occurring only in the river.

Rydlo states that the possibilities of comparing the historic status of vegetation of aquatic macrophytes in the majority of Bohemian and Moravian rivers are very limited, because most of the researchers did not carry out systematic survey or surveyed from the river bank and the results are; therefore, not providing a full picture of the presence of macrophytic species in rivers. From the communities of macrophytes that used to be more widely spread in the rivers, the most commonly disappearing associations include Potametum lucensis (Hueck, 1931), Potametum natansis Hild (1959), Potametum denso - nodosi de Bolós (1957), Potametum perfoliati Mijlan (1933), Potametum pectinati Carstensen ex Hilbig (1971), and the community with dominant Potamogeton praelongus a Elodeetum canadensis Nedelcu (1967). Very stable are communities of Phragmitetum australis Savič (1926), Typhetum angustifoliae Pignatti (1953) and communities with the dominant species of Nuphar lutea (Rydlo, 2001). 
Jan Rydlo studied vegetation in the river basin of the conjoined Orlice River (Rydlo, 2008), as well as species and communities in stagnant waters (river pool above the sand quarry). Flora and vegetation of pools is dependent on the levels of shading and on the depth of the water. Highly shaded pools usually do not contain much vegetation apart from the alliance of Lemno - Spirodeletum and rarely species of Lemna trisulca and Iris pseudacorus. Partially shaded and non-shaded pools contain numerous communities and species of aquatic macrophytes. Amongst those not anchoring in the river bed belong Lemnion minoris, Utricularion vulgaris and Hydrocharition. On the other hand, communities anchoring their roots in the river bed are represented by Nymphaeo albae - Nupharetum luteae, Batrachietum circinati, Batrachietum trichophylli, Potamion lucentis and Potamion pusilli. There are mainly reed beds in the shallow sections of the river, represented by the communities of Glycerietum maximae and Sparganietum erecti, around the river banks then alliances of tall rushes (Rydlo, 2008). Rydlo junior points out that due to the insufficient amount of data on the presence of macrophytic vegetation in the pools of the Orlice River, it is not possible to compare the current status with the past. It is; however, possible to capture the changes in occurrence of some aquatic macrophytes from historic records. Nymphaea alba is a critically endangered species occurring in the river basins of the River Elbe and in Moravia. In Hradec Králové - in Slezské Předměstí it was listed by Bílek (1984); Rydlo found colourful cultivars that could belong to this species. The current study confirms these conclusions; they are most likely spontaneously planted cultivars.

Hydrocharis morsus - ranae used to be one of the most common lowland aquatic plants; iy was listed in the dead-end river branches of the Orlice River by Hansgirg (1881), Belicová (1979), Samková (2000), and Prausová (2006); however, Rydlo himself does not list it. The occurrence of Hydrocharis morsus - ranae was currently confirmed in the pool opposite the bakery in Slezské Předměstí.

Endangered species of Czech vegetation - Potamogeton acutifolius - was recorded in the study area by Hansgirg (1881), Cernohous recorded it in the dead-end river branch by Malšovice (1978); it was also listed in Slezské Předměstí by Prausová (2006) and Rydlo (2008). The occurrence of this species is currently connected to the localities of Pekelská jezera in Slezské Předměstí and in the temporarily protected area of Rameno by Střibrný rybník near Malšova Lhota.

Potamogeton alpinus is a very rare species; it is known from the lower reaches of the Orlice River, occurring there on one of the lowest situated localities in the Czech Republic (Rydlo, 2008). This species was here recorded by Černohous (Černohous et Husák, 1986), Prausová $(2003 ; 2006)$ and Rydlo jun. (2008). The population survives only in this dead-end river branch.

Potamogeton praelongus was in the river basin around Hradec Králové listed by Hansgirg (1881), Novákova \& Procházka (1976), Černohous (1986), Rydlo (1995), Prausova (2003; $2004 ; 2006 ; 2010$ ) and Rydlo junior (2008). A large population thrived on Jezuitska jezera in the past; however, the locality was later destroyed by commercial fishing when the pool started supporting herbivorous fish in order to reduce Potamogeton complicating fishing (Rydlo, 1995b). Successful planting of Potamogeton praelongus was carried out as a part of the rescue programme in the dead-end river branch of Kašparovo jezero (Prausová, 2010). Rydlo jun. (2008) found several individuals under the Malšovice Bridge; however, the plants did not survive. Currently undergoing works include the preparation of revitalisation of the temporarily protected area. The works will consist of removal of the mud sediment in the dead-end river branch and reconstruction of the shore vegetation leading to the optimisation of habitat conditions for this specially protected species. 
Vávra M.: Floodplain of the Orlice River (Eastern Bohemia, Czech Republic): the natural centre of biodiversity

The strongly endangered Potamogeton perfoliatus was in the stagnant and flowing waters of the Orlice River recorded only by Hansgirg (1881), there is no record of this species in the newer literature. Potamogeton perfoliatus was found in the isolated water habitat of Pod auty, but only several individuals were recorded. Rydlo jun. (2008) reckons that this species probably completely disappeared from the river basin of the Orlice River. Ocassional occurrence is still possible; however, this is likely to be the result of spontanneous planting, making its appearance in Eastern Bohemia every now and then (Gerža, 2012).

The water activity in the Orlice River supports spreading of allochthones plants, disturbing the natural composition of communities (Kovár et al., 2007). Growing distribution of Japanese knotweed (Reynoutria japonica) and Himalayan balsam (Impatiens glandulifera) is so intense that natural communities along the river decline (Faltysová et al., 2002). Prausová (2009) also states that the river basin of the conjoined Orlice River between Hradec Králové a Týniště nad Orlicí is negatively influenced by the spreading of geographically introduced and invasive species of plants. Impatiens glandulifera grows on several parts of the study area (locality Hluboké jezero, Kašparovo jezero and Sýkorky); Impatiens parviflora is a common part of the communities in the study area; Reynoutria japonica was found on the following localities: Bejkovna, Hluboké jezero and Rameno by Stříbrný rybník. South American species of Solidago canadensis and Solidago gigantea are common in the adjacent biotopes. Further highly invasive species recorded here include Acer negundo, Populus $x$ canadensis and Robinia pseudoacacia, but also geographically introduced Elodea canadensis and Juncus tenuis; however, these species do not behave in an invasive way in the river basin of the Orlice River (Prausová, 2009). Elodea canadensis was until recently considered to be an invasive species (Pyšek et al., 2012).

A desirable solution to this problem is a complete eradication of invasive species in the entire river basin of the Orlice River, because the spreading of the species is connected directly with the channel of the river as well as all its tributaries (Prausová, 2009). The invasion of Impatiens glandulifera is necessary to be regulated by mechanical disturbance to the vegetation cover of this species or mowing at the time of flowering, pulling out and crashing each individual stem before further flowers occur. Application of herbicides is not desirable due to the co-existence with numerous rare biotopes on the invaded localities. Systematic reduction of the species of Impatiens glandulifera can gradually completely eliminate the plant from the locality.

The vegetation of aquatic macrophytes in dead-end river branches and pools is subject to the influence of river dynamics in the sense of disturbance and already by a five year flood (Q5) are these distant localities flooded. Disturbance of regenerative parts of the plants can; therefore, be carried out.

\section{CONCLUSIONS}

Based on the available information, it is possible to regard the river basin of the Orlice River near Hradec Králové as a very valuable refugium for rare taxons of aquatic and wetland species of plants. We recorded 449 taxons of vascular plants connected to a number of valuable communities in this research. Many rare species have been surviving here decades after the regulation of the river channel. 


\section{ACKNOWLEDGEMENT}

The article and the field survey was supported from the funds for specific research of the Faculty of Science, University of Hradec Králové, funded by the Ministry of Education, Youth and Physical Education of the Czech Republic, number 2122/2015. I would like to thank to RNDr. Romana Prausova, Ph.D. for her help in field as well as consultations during the processing of the data. I would also like to thank Prof. RNDr. Pavel Kovár, CSc. For consultations and interpretation of the problems.

\section{REFERENCES}

Abeli, T., Rossi, G., Smolders, A. J. P., et Orsenigo, S., (2014). Nitrogen pollution negatively affects Stratiotes aloides in Central-Eastern Europe. Implications for translocation actions. Aquatic Conserv., 24(5): 724-729.

Černohous, F. et Husák, Š., (1986). Macrophyte vegetation of Eastern and North-Eastern Bohemia, Folia Geobot. Phytotax., Praha, 21: 113-161.

Danihelka, J., Chrtek, J. Jr. et Kaplan, Z., (2012), Checklist of vascular plants of the Czech Republic. Preslia 84: 647-811.

Dieter, C.D., (1990). The importance of emergent vegetation in reducing sediment resuspension in wetlands. J. Freshwat. Ecol., 5(4): 467-473.

Drincard, M. K., Kershner, M. W., Romito, A., Nieset, J. et de Szalay, F. A., (2011). Responses of plants and invertebrate assemblages to water-level fluctuation in headwater wetlands. J. North Am. Benthol, Soci., 30(4): 981-996.

Faltys, V., (1993). Přehled vyhynulých, nezvěstných a ohrožených taxonů na území východnich Čech, AOPK Pardubice, 24 pp.

Faltysová, H., (1996). Př́rodní park Orlice. Okresní úřady v Hradci Králové, Rychnově nad Kněžnou, Ústí nad Orlicí a Úřad města Hradec Králové ve spolupráci s Agenturou ochrany př́rody a krajiny v Pardubicích.

Faltysová, H., Mackovčin, P., Sedláček, M. et al., (2002). Královéhradecko. In: Mackovčin P. et Sedláček M. (eds.): Chráněná územi ČR, svazek V., (410 pp.), Agentura ochrany př́rody a krajiny a EkoCentrum Brno, Praha.

Grohmannová, L., (2012). Succession and the development of alluvial communities after a flood in 1997. Journal of Landscape Ecology, 5(1): 29-49.

Grulich, V., (2012). Red List of vascular plants of the Czech Republic: 3rd edition. Preslia, Praha, 84: 631-645.

Haslam, S. M., (1978). Aquatic plant management in semi-natural streams: the role of marginal vegetation. J. Environ. Manage., 6: 213-221.

Chytrý, M., (2011). Vegetace České republiky 3: Vodní a mokřadní vegetace. Academia, Praha, 828 pp.

Kaplan, Z., (2002). Úzkolisté druhy rodu Potamogeton v květeně České republiky III. P.obtusifolius a P. friesii. - Preslia 74: 267-250, Praha.

Kaplan, Z., (2002). Úzkolisté druhy rodu Potamogeton v květeně České republiky IV. Potamogeton pusillus s.1. a P.trichoides. - Preslia 74: 345-371, Praha.

Kaplan, Z., (2003). Úzkolisté druhy rodu Potamogeton v květeně České republiky V. P.pectinatus. - Preslia 75: 165-181, Praha. 
Vávra M.: Floodplain of the Orlice River (Eastern Bohemia, Czech Republic): the natural centre of biodiversity

Kopecký, K., (1967). Metody a cíle studia rozšíření rostlin na říčním pobřeží. Preslia, 39: 421-431, Praha.

Kopecký, K., (1969). Změny druhového složení některých fytocenos v inundaci dolního toku Orlice po záplavách v roce 1965. Preslia 41: 284-296, Praha

Kopecký, K., (1972). K rozšíření a ekologii Carex buekii Wimm. na pobřeží Orlice v severovýchodních Čechách. Časopis národního muzea, řada př́rodovédná 140: 146-149. Praha.

Kopecký, K., (1991). Ustupující a mizející společenstva říčních rákosin s převládajícím druhem Phalaris arundinacea na Divoké a Spojené Orlici. Preslia 63: 305-321, Praha.

Kovár, P., (1983). The grassland communities of the southeastern basin of the Labe river. 2. Synecology. Folia Geobot. Phytotax., 18, 161-187.

Kovář, P., (1996). Polabské aluviální louky a hydrodynamika jejich stanovišt’ jako základ obnovy. In: Straškrabová J. et al. [eds.]: Aluviální louky - jejich současný stav a možnosti obnovy, (109-117 pp.). Příroda - Sborn. Pr. Ochr. Přír., Svazek 4.

Kováŕ, P., (1999). Distribution of heavy metals in stands of macrophytes along a cross-section gradient in the Elbe River lowland (near Poděbrady, Czech Republic). Preslia, 71, 249-256.

Kovář, P., Němcová, L. et Osbornová, J., (1995). Selected macrophytes as biomonitors of heavy metal pollution in waters of the Labe River basin (Czech Republic). Novit. Bot. Univ. Carol., 9, 55-61, Praha.

Kovár̆, P., Janoušková, P., Koppová, J., Köppl, P. et Křivánek, M., (2007). River landscapes and extreme floods in Central Europe (1997, 2002): need for long-term research. Novit. Bot. Univ. Carol., 18: 71-90, 2007, Praha.

Krčan, K. et Kopecký, K., (1960). Příspěvek ke květeně Opočenska a bližšího okolí Týniště nad Orlicí, Acta musei Reginaehradecensis Ser. A.: Scientae naturales 2: 149-189.

Kubát, K., Hrouda, L., Chrtek, J. jun., Kaplan, Z., Kirschner, J. et Štěpánek, J., [eds.], (2002). Klič ke květeně České republiky. Academia, Praha, 928 pp.

Madsen, J. D., Chambers, P. A., James, W. F., Koch, E.W. et Westlake, D. F., (2001). The interaction between water movement, sediment dynamics and submersed macrophytes. Hydrobiologia 444: 71-84.

McDonald, I.A.W., (1988). The history impacts and control of introduced species in the Kruger National Park, South Africa. Trans. R. Soc S. Afr., 46(4): 251-276.

Merritt, D.M., Nilsson, C. et Jansson, R., (2010). Consequences of propagule dispersal and river fragmentation for riparian plant community diversity and turnover. Ecological Monographs, 89(4): 609-626.

Neuhäuslová, Z., (1998). Mapa potenciální prirozené vegetace České republiky. Academia, Praha.

Nováková, H. et Procházka, F., (1976). Nálezová databáze ochrany přirody. AOPK ČR.

O'Brien, W.J., (1981). Use of aquatic macrophytes for wastewater treatments. J. Environ. Eng. Div. ASCE, 107: 681-698.

Prach, K., Černý, R., Gazda, J., Rauch, O. et Kučera, S., (1988). Vegetation in the floodplain of the Lužnice river, Czechoslovakia. Sborn. Agron. Fak. České Budějovice, Fytotech. Ser., 5(2): 85-104. 
Prausová, R., (2003). NATURA 2002 Niva Orlice - západ, H0080. 15 stran textu, 4 mapové př́lohy ZM 1: 10000 (ms.). Depon. In Agentura ochrany přírody a krajiny, Hradec Králové. Prausová, R., Husák, Š., Kaplan, Z., Adamec, L. et Rybka, V., (2004). Řešení záchrany poslední populace rdestu dlouholistého (Potamogeton praelongus WULFEN) v České republice. Ochrana př́rody roč. 59 č. 3: 82-86.

Prausová, R., (2006). Niva Orlice u Hradce Králové. Východočeský botanický zpravodaj Ser. 2006, sv. 6: 4-7, Dobré.

Prausová, R., (2009). Výskyt invazních rostlin v nivě spojené Orlice mezi Hradcem Králové a Týništěm nad Orlicí. Vč. sb. prír. Práce a studie 16 [s. 1.]: [s. n.]: 173-176. Východočeské muzeum Pardubice.

Prausová, R., (2010). Záchranný program pro rdest dlouholistý Potamogeton praelongus. Olga Čermáková, grafické a reklamní studio za finančního přispění programu „Záchranné programy pro zvláště chráněné druhy“ - programu podporovaného grantem z Islandu, Lichtenštejnska a Norska prostřednictvím Finančního mechanismu EHP a finančního mechanismu Norska a MŽP.

Pyšek, P., Danihelka, J., Sádlo, J., Chrtek, J. Jr., Chytrý, M., Jarošík, V., Kaplan, Z., Krahulec, F., Moravcová, L., Pergl, J., Štajerová, K. et Tichý, L., (2012). Catalogue of alien plants of the Czech Republic (2nd edition): checklist update, taxonomic diversity and invasion patterns. Preslia, 84:155-255, Praha.

Ramsar, (1971). Convention on Wetlands of international importance especially as Waterfowl Habitat. Ramsar (iran), 2 february 1971. Un treaty Series no. 14583. as amended by the Paris Protocol, 3 December 1982, and Regina amendments,28 May 1987.

Režný, K., (1977). Zeměpisné poměry. In Roček Z. [ed.]: Př́roda Orlických hor a Podorlicka (229-286 pp.). Státní zemědělské nakladatelství, Praha, 582 pp

Rydlo, J., (1995). Vodní makrofyta Orlice v letech 1984 a 1994. Muzeum a současnost, ser. natur. 9: 149-156.

Rydlo, J., (2001). Změny ve výskytu vodních makrofyt v některých českých a moravských řekách v poslední čtvrtině 20. století. Muzeum a současnost, ser. natur. 15: 51-78, Roztoky.

Rydlo, J., (2008). Vodní flóra v nivě Orlice. Muzeum a současnost, ser. natur. 23: 62-126, Roztoky.

Rybáŕ, P. et al., (1989). Př́rodou Krkonoš po Vysočinu: regionální encyklopedie. Kruh, Hradec Králové, 392 pp.

Samková, V., (1999). K rozššření některých vzácných a ohrožených druhů rostlin ve východních Čechách. Acta musei Reginaehradecensis, Ser. A.: Scientae naturales 27: 19-74.

Smolders, A.J.P., Lamers, L.P.M., den Hartog, C. et Roelofs, J.G.M., (2003). Mechanisms involved inb the decline of Stratiotes aloides L. in The Netherlands: sulphate as a key variable. Hydrobiologia, 506-509: 603-610.

Skalický, V., (1988). Regionálně fytogeografické členění. In: Hejný S. et Slavík B. [eds.]: Květena ČSR 1, (103-121 pp.). Academia, Praha.

Slavíková, J., (1986). Ekologie rostlin. Státní pedagogické nakladatelství. Praha, 366 pp.

Šámalová, Z., (2007). Labe a Orlice v Hradci Králové: Historie říčních staveb. Povodí Labe, státní podnik, Hradec Králové, 36 pp.

Štěnička, S., (2004). Poorlická naučná stezka. Město Týniště nad Orlicí za finančního přispění obce Albrechtice nad Orlicí a Královéhradeckého kraje z grantového programu CRG 200403 - Budování a úpravy naučných stezek. 2004 (ms.) [Depon. In. Městský úruad 
Vávra M.: Floodplain of the Orlice River (Eastern Bohemia, Czech Republic): the natural centre of biodiversity

Týniště nad Orlicí].

Štěnička, S., (2006). Poorlická naučná stezka. DSO Poorlicko ve spolupráci s RTIC Kostelec nad Orlicí. 14 pp.

Tolasz, R. et al., (2007). Atlas podnebi Česka. ČHMÚ Praha v koedici s Univerzitou Palackého v Olomouci. Praha, Olomouc, 255 pp.

Tomášek, M., (2007). Půdy České republiky. Česká geologická společnost. Praha, 68 pp.

Vávra, M., (2014). Sukcese odstavených ramen řeky Orlice u Hradce Králové. Vegetation succession in oxbows of the Orlice River at Hradec Králové. - Ms. [Dipl. Thesis - Faculty of Science, University of Hradec Králové, Czech Republic]. 141 pp. [in Czech]

Vyhláška č. 395/1992 k zákonu ČNR č. 114/1992 Sb., o ochraně přírody a krajiny

Werie, G. et Jorga, W., (1981). Aquatic macrophytes - a potential resource. Water Qual. B, 6(4): 104-108.

\section{Internet sources}

http://gis.kr-kralovehradecky.cz

http://botany.cz/cs/cerveny-seznam/

www.belec.trebechovicko.cz

www.zachranneprogramy.cz 